\title{
Maize Fertigation with Treated Olive Mill Wastewater: Effects on Crop Production and Soil Properties
}

\author{
Maria I. Kokkora ${ }^{1}$, Chryssoula Papaioannou ${ }^{1}$, Panagiotis Vyrlas ${ }^{1}$, Konstantinos Petrotos $^{1}$, Paschalis Gkoutsidis ${ }^{1}$ \\ \& Christos Makridis ${ }^{1}$ \\ ${ }^{1}$ Department of Agricultural Engineering Technologists, Technological Educational Institute of Thessaly, Larissa, \\ Greece \\ Correspondence: Maria I. Kokkora, Department of Agricultural Engineering Technologists, Technological \\ Educational Institute of Thessaly, Larissa, 41110, Greece. Tel: 30-2410-684-749. E-mail: mkokkora@teilar.gr
}

Received: August 1, 2015 Accepted: September 2, 2015 Online Published: September 7, 2015

doi:10.5539/sar.v4n4p66 URL: http://dx.doi.org/10.5539/sar.v4n4p66

\begin{abstract}
The present study investigates the potential of olive mill wastewater, treated by microfiltration and XAD4 macroporous resin, to be used as liquid fertilizer in maize production through a 2-year field experiment. The treated olive mill wastewater (T-OMWW) was applied at two rates of $25 \mathrm{t}$ and $50 \mathrm{t}$ per ha per year, supplemented with mineral fertilization. There was also a treatment involving the application of only T-OMWW at the rate of $50 \mathrm{t}$ per ha per year, and an only mineral fertilizer treatment. Mineral fertilizers and T-OMWW were applied progressively through a drip irrigation system.

Maize grain and soil analysis showed that T-OMWW was capable to meet crop requirements in $\mathrm{N}, \mathrm{P}$ and $\mathrm{K}$, and increase soil N, P and K availability. There was a tendency for increasing soil $\mathrm{Na}$ and electrical conductivity (EC) using the higher rate of T-OMWW. Therefore, for sustainable agriculture, it may be safer to apply the T-OMWW at the lower rate of $25 \mathrm{t}$ per ha per year, or use the higher rate of $50 \mathrm{t}$ per ha every other year.
\end{abstract}

Keywords: clay loam soil, kernel protein content, liquid fertilizer, microfiltration, XAD4 resin, yield

\section{Introduction}

Olive oil consumption is associated with many health benefits, including protective effects against cardiovascular diseases (Covas, 2007), cognitive decline (Berr et al., 2009) and possibly breast cancer (Escrich, Moral, \& Solanas, 2011). The olive oil extraction process, however, involves the generation of large amounts of olive mill wastewater (OMWW), a by-product that constitutes serious environmental problem in the Mediterranean region, due to its high polluting load. OMWW is characterized by high content of solids and organic compounds, high COD content, phytotoxic properties and resistance to biodegradation caused by its phenolic compounds (Zirehpour, Jahanshahi, \& Rahimpour, 2012; Zaglis, Vavouraki, Kornaros, \& Paraskeva, 2013).

Olive oil production in Greece is mainly carried out by small or medium enterprises that usually apply the untreated OMWW to nearby land, in order to avoid treatment costs. Crop response to OMWW application is variable. Research has shown that olive fruit yield and quality were not affected by OMWW application (Chartzoulakis, Psarras, Moutsopoulou, \& Stefanoudaki, 2010). Ryegrass and proteic pea yields were increased with untreated OMWW application, whereas clover yield was negatively affected (Montemurro, Diacono, Vitti, \& Feri, 2011). In another study, although maize growth was not affected, plant stress parameters increased following the application of untreated OMWW (Belaqziz et al., 2008). Hanifi and El Hadrami (2008) found increased maize yield following moderate and progressive OMWW application. Germination problems are also observed due to phytotoxic effects of the phenolic compounds contained in the OMWW (Mekki, Dhouib, \& Sayadi, 2007; Massoudinejad, Arman, \& Aghayani, 2014). The application of untreated OMWW to agricultural soil may increase soil organic matter, available P and K (Montemurro et al., 2011), and total N content, but also soil electrical conductivity and salinity (Belaqziz, Lakhal, Mbouobda, \& El Hadrami, 2008), and modify the equilibrium of useful soil microorganisms (Barbera, Mauciery, Cavallaro, Ioppolo, \& Spagna, 2013).

The phenolic compounds contained in the OMWW are natural antioxidants, with commercial and economic interest. Hence, the treatment of OMWW aiming at the recovery of the polyphenols could result in economic 
benefits for the olive mill, since the phytotoxic polyphenols will have been removed from the effluent. Membrane filtration of OMWW may result in a significant decrease of its organic load and suspended solids content (Russo, 2007, Zirehpour et al., 2012), and also in polyphenols separation from the mass of waste (Cassano, Conidi, \& Drioli, 2011; Petrotos, Lellis, Kokkora, \& Gkoutsidis, 2014; Rahmanian, Jafari, \& Galanakis, 2014). OMWW treatment with microfiltration resulted in polyphenols separation in the permeate (Petrotos et al., 2014). Polyphenols may then be successfully removed with the use of suitable resins (Weisz, Schneider, Schweiggert, Kammerer, \& Carle, 2010; Petrotos, Gkoutsidis, Kokkora, Giankidou, \& Tsagkarelis, 2013; Zaglis et al., 2015). The recovered polyphenols may be utilized in the pharmaceutical, cosmetic and food industry and the remaining effluent will have decreased phytotoxic properties, and thus it may be more safely used in agriculture.

Research on the agronomic effects of treated OMWW application to agricultural soil is limited, and mainly involves OMWW that has been treated by chemical or biological techniques (Cereti et al., 2004, Barbera, Maucieri, Ioppolo, Milani, \& Cavallaro, 2014; Moraetis, Stamati, Nikolaidis, \& Kalogerakis, 2014). In this study, the effluent produced following the treatment of OMWW by microfiltration and XAD4 macroporous resin was applied by fertigation to maize production in a two-year field experiment. The aim of the study was to investigate its effects on crop production, with particular regards to grain yield and quality, and soil properties.

\section{Method}

\subsection{Treated Olive Mill Wastewater (T-OMWW)}

In 2013 and 2014, a sample of approximately 10 t of OMWW was collected each year from "Alevizos" olive mill, located in Pyrgetos village, Larissa, central Greece. Each year, the raw OMWW was initially centrifuged at $1200 \mathrm{rpm}$ using a rotary finisher bearing a stainless screen with openings of $150 \mu \mathrm{m}$ diameter. This first step aimed at separating the suspended solids contained in OMWW, in the form of sludge, in order to avoid clogging of the membrane used in the next step.

In the second step, the centrifuged OMWW was filtered using a ceramic microfiltration membrane of $200 \mathrm{~nm}$ pore size in order to separate the polyphenols in the permeate from the mass of waste (retentate). The effluent produced as permeate in this step was suitable to be applied through a drip irrigation system, with limited risk of emitters clogging.

As a final step, the permeate produced in the second step was passed through a column filled with XAD4 macroporous resin, which has the ability to retain selectively the polyphenols (Petrotos et al., 2013), aiming to recover the polyphenols and minimize any phytotoxic effects of the remaining effluent. The polyphenolic content of the remaining effluent was approximately $20-30 \%$ of the initial polyphenolic content of the input material.

The treated OMWW (the remaining effluent of the final stage) was considered for utilization in agriculture as a liquid fertilizer. Some quality properties of the treated OMWW (T-OMWW) are presented in Table 1 for each year. Table 1 shows that T-OMWW quality parameters varied between the two years, especially in respect of available nutrients. This variability is attributed to the annual variation of the nutritional quality of olives (input material) that may be processed by the olive mill each year, leading therefore to differences in the quality of OMWW and also T-OMWW.

Table 1. Treated OMWW physicochemical properties in 2013 and 2014

\begin{tabular}{|c|c|c|}
\hline Parameter & 2013 & 2014 \\
\hline $\mathrm{pH}$ & 4.73 & 6.15 \\
\hline $\mathrm{EC}\left(\mathrm{mS} \mathrm{cm}^{-1}\right)$ & 9.91 & 8.30 \\
\hline Salinity (\%) & 8.9 & 6.0 \\
\hline Solid residue $\left(105^{\circ} \mathrm{C}\right)(\%)$ & 4.15 & 9.94 \\
\hline Available $\mathrm{P}\left(\mathrm{mg} \mathrm{L}^{-1}\right)$ & 1680 & 256 \\
\hline Extractable K $\left(\mathrm{mg} \mathrm{L}^{-1}\right)$ & 1440 & 64 \\
\hline $\mathrm{NH}_{4}-\mathrm{N}\left(\mathrm{mg} \mathrm{L}^{-1}\right)$ & 86 & 3.11 \\
\hline $\mathrm{NO}_{3}-\mathrm{N}\left(\mathrm{mg} \mathrm{L}^{-1}\right)$ & - & 0.1 \\
\hline
\end{tabular}

Note. EC: Electrical conductivity. 


\subsection{Field Experiment}

A field experiment was carried out on an Inceptisol clay loam soil (41\% sand, $20 \%$ silt, $39 \%$ clay) at the experimental farm of Technological Educational Institute of Thessaly, Larissa, Greece, in 2013 and 2014. Topsoil $(0-0.3 \mathrm{~m}$ depth) quality properties in the beginning of the experiment are presented in Table 2.

Table 2. Topsoil (0-0.3 m depths) quality properties at the beginning of the experiment

\begin{tabular}{cccccccc}
\hline $\mathrm{pH}$ & $\begin{array}{c}\mathrm{EC} \\
(\mathrm{mS} \mathrm{cm})\end{array}$ & $\begin{array}{c}\text { O.M. } \\
(\%)\end{array}$ & $\begin{array}{c}\mathrm{CaCO}_{3} \\
(\%)\end{array}$ & $\begin{array}{c}\text { Total N } \\
\left(\mathrm{g} \mathrm{kg}^{-1}\right)\end{array}$ & $\begin{array}{c}\text { Olsen P } \\
\left(\mathrm{mg} \mathrm{kg}^{-1}\right)\end{array}$ & $\begin{array}{c}\text { Extr. K } \\
\left(\mathrm{g} \mathrm{kg}^{-1}\right)\end{array}$ & $\begin{array}{c}\text { Extr. Mg } \\
\left(\mathrm{g} \mathrm{kg}^{-1}\right)\end{array}$ \\
\hline 7.3 & 0.723 & 1.4 & 1.8 & 0.8 & 6.5 & 0.47 & 1.42 \\
\hline
\end{tabular}

Note. EC: Electrical conductivity, O.M.: Organic Matter, Extr.: Extractable.

The experimental design involved four treatments: i) control (C): mineral fertilization only, ii) application of T-OMWW at the rate of $50 \mathrm{t} \mathrm{ha}^{-1}(50 \mathrm{~W})$, iii) combined application of T-OMWW at the rate of $50 \mathrm{tha}^{-1}$ with mineral fertilization $(50 \mathrm{~W}+\mathrm{f})$, and iv) combined application of T-OMWW at the rate of $25 \mathrm{t} \mathrm{ha}^{-1}$ with mineral fertilization $(25 \mathrm{~W}+\mathrm{f})$. In 2013 , the mineral fertilizer addition was equal to $200 \mathrm{~kg} \mathrm{~N}$ per ha for each of the three treatments that received mineral fertilizer. Fertilizer nitrogen was applied as ammonium nitrate (34.5-0-0). In 2014 , the mineral fertilization for the control treatment corresponded to the addition of $110 \mathrm{~kg} \mathrm{~N}, 180 \mathrm{~kg} \mathrm{P}_{2} \mathrm{O}_{5}$, $27 \mathrm{~kg} \mathrm{~K}_{2} \mathrm{O}$ and $78 \mathrm{~kg} \mathrm{SO}$ per ha. The mineral fertilizer addition for each of the combined T-OMWW and mineral fertilizer treatments was $55 \mathrm{~kg} \mathrm{~N}, 131 \mathrm{~kg} \mathrm{P}_{2} \mathrm{O}_{5}, 27 \mathrm{~kg} \mathrm{~K}_{2} \mathrm{O}$ and $17 \mathrm{~kg} \mathrm{SO}_{3}$ per ha. Three fertilizers were used in 2014: peckacid (0-60-20), urea phosphate (17.5-44-0) and ammonium sulfate (21-0-0). Each year, each treatment was applied to an individual plot of $60 \mathrm{~m}^{2}(6 \mathrm{~m} \mathrm{x} 10 \mathrm{~m}$, including 8 plant rows), using a complete randomized block design with four replicates. Maize (Zea mays) was used as the monitoring crop. Crop sowing was at the rate of approximately 8.6 seeds $\mathrm{m}^{-2}$, and took place on May 25, 2013 and June 18, 2014.

In order to ensure germination, sprinkler irrigation was applied each year after sowing for seedling establishment. Water, mineral fertilizers and T-OMWW were applied through a drip irrigation system, employing four manifolds. Each manifold supplied a set of four plots with one drip lateral per two adjusted plant rows. The volume of required water controlled by a flow meter installed at upstream of each manifold. The $20 \mathrm{~mm}$ diameter emitting pipe used is commonly utilized for field crop irrigation, with pressure compensating emitters at $1 \mathrm{~m}$ spacing, discharging $3.6 \mathrm{~L}$ per hour.

Treated OMWW was applied through the drip system utilizing a $120 \mathrm{~L}$ tank connected to the main line and manipulating a throttling valve to create a differential pressure level. Each treatment received water and T-OMWW filtered through 1" conventional manual cleaning disk filters of $150 \mathrm{mesh}$. A preliminary 120 mesh screen filtration was operated on the main pipeline of the system. The secondary filters were cleaned after each T-OMWW application. Manual flushing of the laterals was performed every third week.

In 2013, five applications of T-OMWW took place between 1 July and 8 August, delivering in total $300 \mathrm{~L}$ for each plot receiving T-OMWW at the rate of $50 \mathrm{t} \mathrm{ha}^{-1}$ and $150 \mathrm{~L}$ for each plot receiving T-OMWW at the rate of $25 \mathrm{t} \mathrm{ha}^{-1}$. In 2014, six applications of T-OMWW took place between 1 August and 5 September, delivering in total $300 \mathrm{~L}$ for each plot receiving T-OMWW at the rate of $50 \mathrm{tha}^{-1}$ and $150 \mathrm{~L}$ for each plot receiving T-OMWW at the rate of $25 \mathrm{tha}^{-1}$.

All treatments were irrigated at $100 \%$ crop evapotranspiration $\left(\mathrm{ET}_{\mathrm{c}}\right)$ during the full season, in both years of the experiment. An automatic weather station in the experimental field measured rainfall, solar radiation, air temperature and humidity, and wind speed. These parameters were used to calculate daily reference evaporation $\left(\mathrm{ET}_{\mathrm{o}}\right)$. The irrigation applied through the drip system was scheduled using reference evaporation and growth stage based crop coefficient, according to FAO-56 methodology (Allen, Pereira, Raes, \& Smith, 1998). Table 3 shows monthly values of the measured parameters during the experimental periods. In 2013, there was $108 \mathrm{~mm}$ of rainfall during the experiment.

In 2013, there was $108 \mathrm{~mm}$ of rainfall during the experiment. Total watering during the growing season was 500 $\mathrm{mm}$ with $312 \mathrm{~mm}$ applied through the drip system for all treatments. In 2014, there was $96 \mathrm{~mm}$ of rainfall during the experiment, the majority of which took place after the irrigation period. Total watering during the growing season was $576 \mathrm{~mm}$, with $480 \mathrm{~mm}$ applied through the drip system for all treatments. 
Table 3. Monthly total rainfall, maximum (max) and minimum (min) temperature and humidity, average (aver.) wind speed and solar radiation during the two experimental periods

\begin{tabular}{|c|c|c|c|c|c|c|c|c|c|c|c|c|c|c|}
\hline & \multicolumn{2}{|c|}{$\begin{array}{l}\text { Total rainfall } \\
\text { (mm) }\end{array}$} & \multicolumn{2}{|c|}{$\begin{array}{c}\text { Max air } \\
\text { temperature } \\
\left({ }^{\circ} \mathrm{C}\right)\end{array}$} & \multicolumn{2}{|c|}{$\begin{array}{c}\text { Min air } \\
\text { temperature } \\
\left({ }^{\circ} \mathrm{C}\right)\end{array}$} & \multicolumn{2}{|c|}{$\begin{array}{c}\text { Max humidity } \\
(\%)\end{array}$} & \multicolumn{2}{|c|}{$\begin{array}{c}\text { Min humidity } \\
(\%)\end{array}$} & \multicolumn{2}{|c|}{$\begin{array}{l}\text { Aver. wind } \\
\text { speed } \\
\left(\mathrm{m} \mathrm{s}^{-1}\right)\end{array}$} & \multicolumn{2}{|c|}{$\begin{array}{l}\text { Aver. solar } \\
\text { radiation } \\
\left(\mathrm{W} \mathrm{m}^{-2}\right)\end{array}$} \\
\hline & 2013 & 2014 & 2013 & 2014 & 2013 & 2014 & 2013 & 2014 & 2013 & 2014 & 2013 & 2014 & 2013 & 2014 \\
\hline Apr & 2.4 & 75.2 & 31.6 & 25.2 & 2.4 & 0.4 & 100 & 100 & 19.0 & 24.9 & 1.5 & 1.5 & 519.6 & 430.5 \\
\hline May & 56.4 & 10.2 & 34.8 & 33.2 & 8.5 & 5.5 & 100 & 100 & 11.5 & 13.2 & 1.7 & 1.4 & 557.3 & 567.3 \\
\hline Jun & 72.6 & 23.4 & 38.4 & 40.0 & 9.0 & 10.9 & 100 & 100 & 7.8 & 11.7 & 1.5 & 1.4 & 616.5 & 597.7 \\
\hline Jul & 50.2 & 12.2 & 38.9 & 38.0 & 14.2 & 14.5 & 100 & 100 & 19.6 & 18.5 & 1.2 & 1.7 & 632.9 & 648.5 \\
\hline Aug & 0.0 & 8.8 & 38.7 & 40.4 & 14.6 & 13.5 & 99.5 & 100 & 14.0 & 16.2 & 1.4 & 1.5 & 596.7 & 594.9 \\
\hline Sept & 13.0 & 81.6 & 36.5 & 34.1 & 8.8 & 7.5 & 100 & 100 & 13.2 & 26.0 & 1.3 & 1.3 & 478.4 & 451.1 \\
\hline Oct & 15.0 & 85.8 & 27.9 & 29.6 & 3.8 & 5.5 & 100 & 100 & 13.3 & 28.8 & 0.8 & 0.8 & 311.4 & 234.2 \\
\hline
\end{tabular}

\subsection{Measurements and Analysis}

Crop production was determined at harvest (September 20, 2013 and September 25, 2014). Maize ears were harvested by hand from 10 maize plants from the central 4 rows of each experimental plot. Maize ears were dried in a ventilated oven at $55^{\circ} \mathrm{C}$, until constant weight. After drying, maize kernels were separated from the rest of the ear, weighted, grinded, and then analyzed for protein, starch, fiber, oil and ash content, using an automatic near infrared analyzer. Reported kernel protein, starch, fiber, oil and ash content were corrected to $0 \%$ moisture content.

Soil samples were collected from each plot three days after harvest each year. Samples were taken from 0-30 cm depth and analyzed for $\mathrm{pH}$ (1:1 water), EC (1:1 water), Olsen P, Kheldahl N, extractable K, Na (determined in ammonium acetate extract by flame photometry), $\mathrm{Ca}, \mathrm{Mg}$ (determined in ammonium acetate extract by atomic absorption), $\mathrm{NH}_{4}-\mathrm{N}$ and $\mathrm{NO}_{3}-\mathrm{N}$ (determined in $\mathrm{KCl}$ extract by phasmatophotometry).

The effect of each treatment on crop and soil measured variables were assessed by ANOVA at the level of statistical significance of $\mathrm{p}<0.05$, and means were separated by Duncan's multiple range test using the statistical program SPSS (SPSS Inc., Edit. 17.0, Chicago, USA).

\section{Results and Discussion}

\subsection{Maize Kernel Yield and Quality}

In both years of experimentation, the effect of T-OMWW application on maize kernel dry matter yield was not significant. As shown in Figure 1, however, in the second year there was a tendency for lower yield with the application of T-OMWW at the rate of $50 \mathrm{t}$ per ha. This finding may be indicative of potential salinity effects on the crop. The higher salt concentration in the root zone resulting from the higher rate of T-OMWW application by drip irrigation may have contributed to the reduced yield, since maize is a salinity sensitive crop (Mahajan $\&$ Tuteja, 2005). Research work by Hanifi and El Hadrami (2008) showed variable toxicity levels depended on the salinity and phenolic content of olive mill wastewaters. They also showed that the application of OMWW at the rate of $30 \mathrm{~m}^{3} \mathrm{ha}^{-1}$ to maize production resulted in no physiological damage to the crop, which agrees with our results showing lack of adverse effects on yield with the lower application rate of T-OMWW $\left(25 \mathrm{t} \mathrm{ha}^{-1}\right)$. 


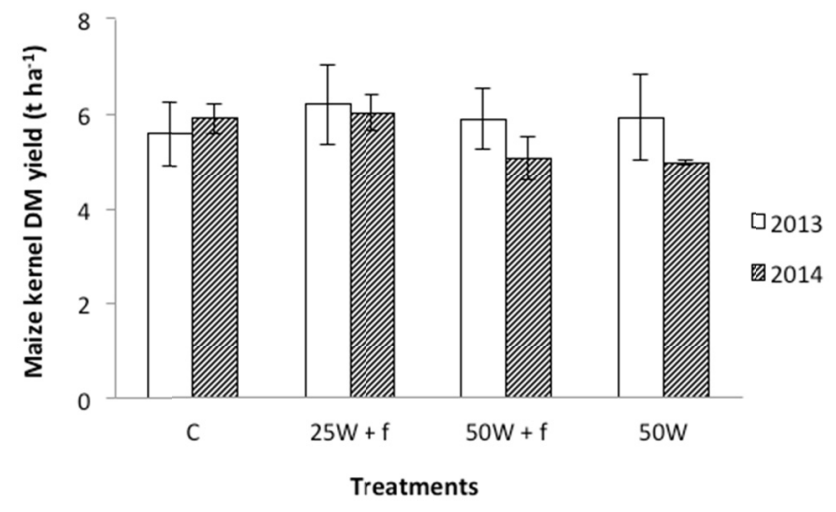

Figure 1. Maize kernel dry matter (DM) yield (in kg per ha) as affected by the different treatments, in the first and second year of the experiment. Error bars represent the standard error of the mean. (C: Control (mineral fertilization only), $25 \mathrm{~W}+\mathrm{f}: 25 \mathrm{tha}^{-1}$ year $^{-1}$ of T-OMWW plus mineral fertilization, $50 \mathrm{~W}+\mathrm{f}: 50 \mathrm{tha}^{-1}$ year $^{-1}$ of

T-OMWW plus mineral fertilization, 50W: $50 \mathrm{tha}^{-1}$ year $^{-1}$ of T-OMWW only)
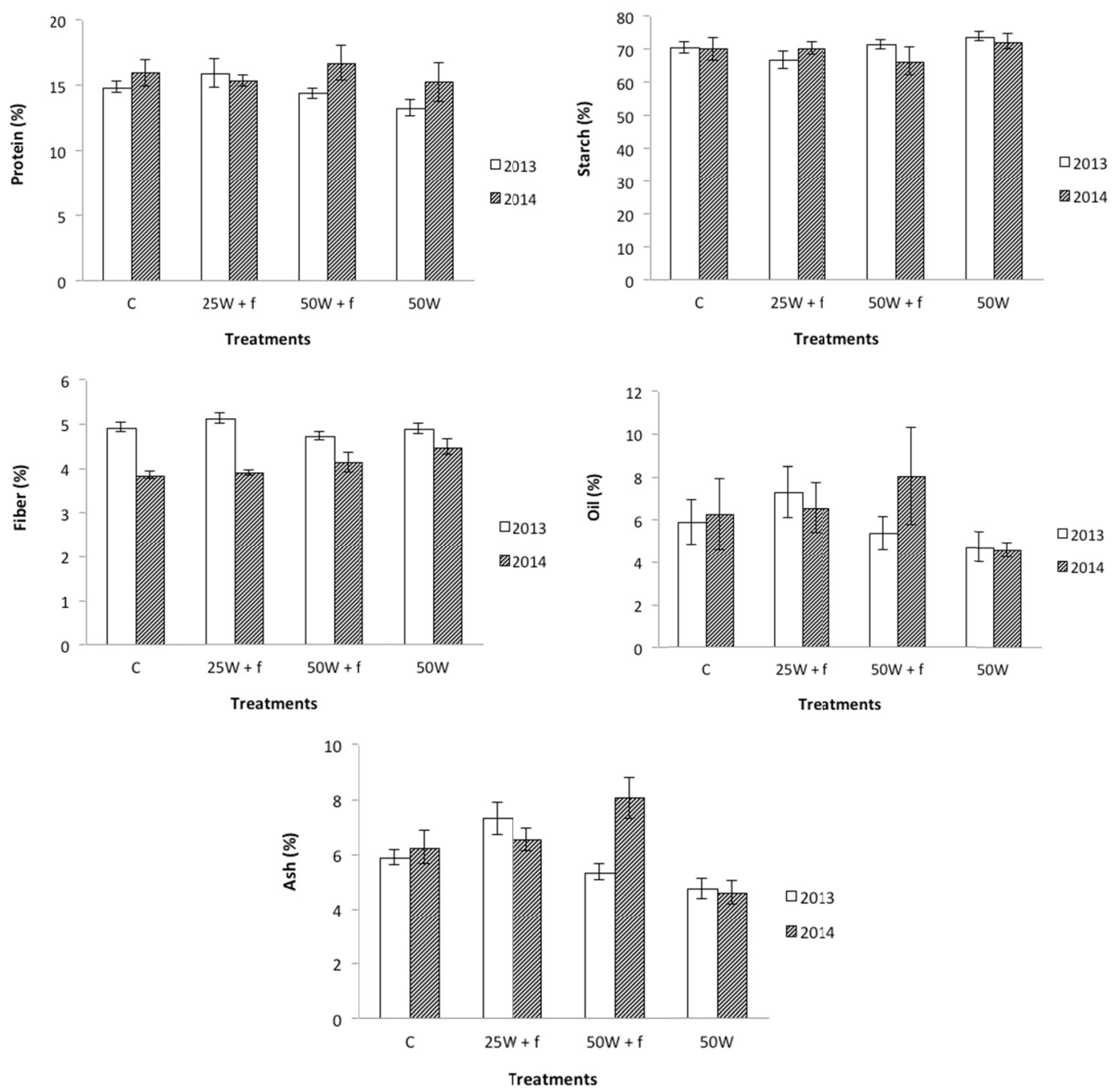

Figure 2. Maize kernel protein (top left), starch (top right), fiber (middle left), oil (middle right) and ash (bottom) content as affected by the different treatments, in the first and second year of the experiment. Error bars represent the standard error of the mean. (C: Control (mineral fertilization only), $25 \mathrm{~W}+\mathrm{f}: 25 \mathrm{t} \mathrm{ha}^{-1} \mathrm{year}^{-1}$ of T-OMWW plus mineral fertilization, $50 \mathrm{~W}+\mathrm{f}: 50 \mathrm{tha}^{-1}$ year $^{-1}$ of T-OMWW plus mineral fertilization, $50 \mathrm{~W}: 50 \mathrm{tha}^{-1}$ year $^{-1}$ of T-OMWW only) 
Kernel quality parameters are presented in Figure 2. The application of T-OMWW, with or without the addition of mineral fertilization, resulted in similar content of protein with the control treatment in both years of the experiment. Mean kernel protein content was $15.2 \%$ (2-year average), which is a relatively high value. Kernel protein content generally increases with higher soil $\mathrm{N}$ availability (Oktem, Oktem, \& Emeklier, 2010; Riedell, 2014), whereas $\mathrm{N}$ deficiency in soils affects negatively $\mathrm{N}$ metabolism and especially protein synthesis (Oktem, Ulger, \& Kirtok, 2001). The similar protein content observed in all four treatments may suggest therefore that soil $\mathrm{N}$ availability for crop uptake was adequate to meet crop nitrogen requirements in all cases. This finding is very important as it indicates the potential of mineral fertilizer nitrogen full substitution by T-OMWW. Kernel starch, ash and oil content also ranged in similar levels with the control treatment in both years of the experiment. The application of T-OMWW at the rate of $50 \mathrm{t} \mathrm{ha}^{-1} \mathrm{year}^{-1}$ resulted in significantly higher kernel fiber content in the second year of the experiment, in comparison to the other two treatments. These findings are indicative of T-OMWW capability to meet crop nutrient requirements and hence to be used as a liquid fertilizer.

In the second year of the study, kernel yield corresponding to the application of $50 \mathrm{t}$ of T-OMWW per ha was about $15 \%$ lower than those of the control or the $25 \mathrm{~W}+\mathrm{f}$ treatment, corresponding to the combined application of T-OMWW at $25 \mathrm{t}$ per ha and mineral fertilization (Figure 1). In order to further explore the potential impact of this non-significant trend in grain yield on kernel component concentrations, the total yield of kernel components on a kg ha ${ }^{-1}$ basis were determined. Yields of protein, starch and fiber, and yields of oil and ash are presented in Figure 3, respectively, for both years of the experiment. There were no significant effects of the different treatments on yields of protein, starch, fiber, oil and ash.
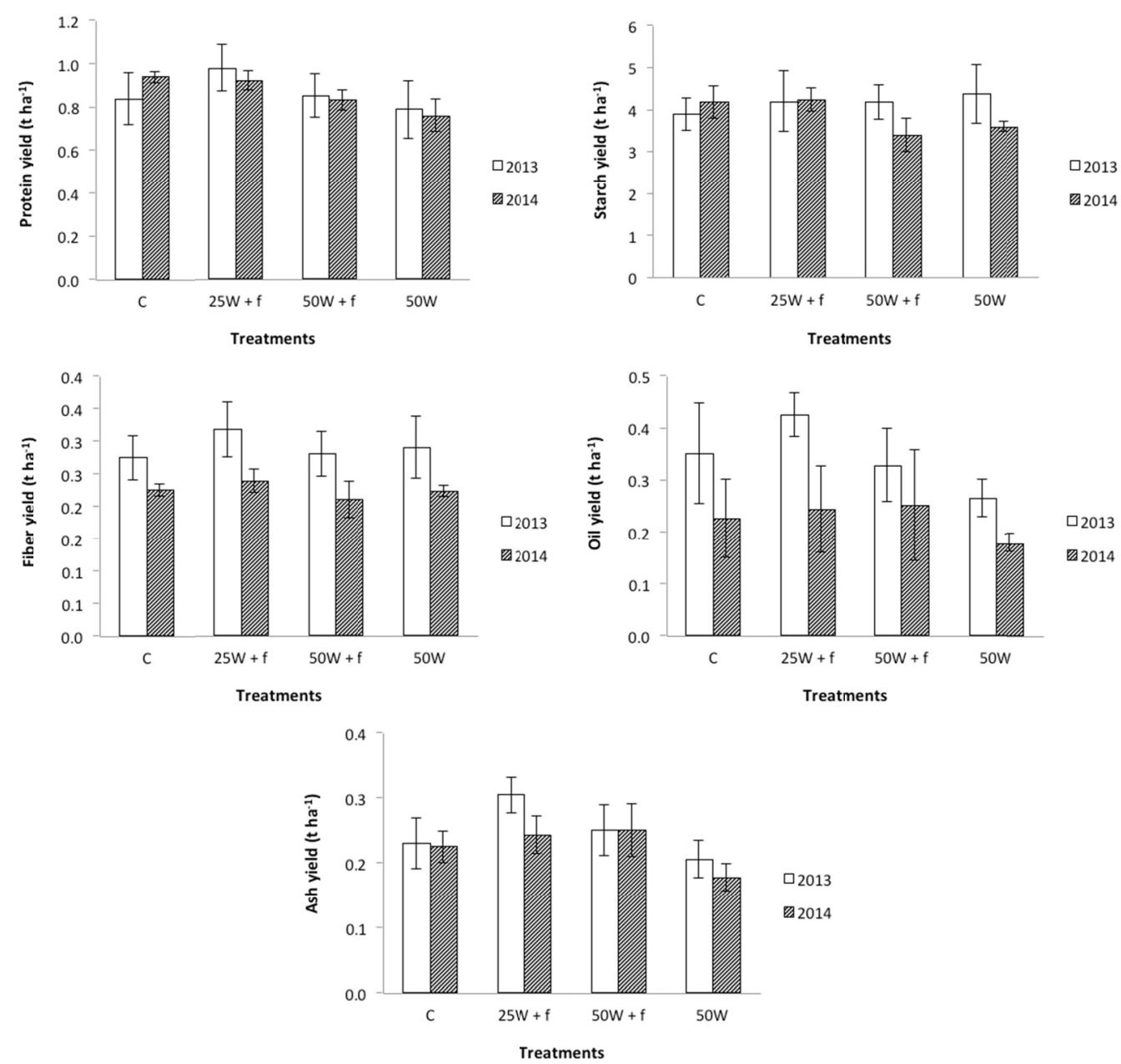

Figure 3. Maize kernel protein (top left), starch (top right), fiber (middle left), oil (middle right) and ash (bottom) yield (in kg per ha) as affected by the different treatments, in the first and second year of the experiment. Error bars represent the standard error of the mean. (C: Control (mineral fertilization only), $25 \mathrm{~W}+\mathrm{f}: 25 \mathrm{t} \mathrm{ha}^{-1} \mathrm{year}^{-1}$ of $^{-}$ T-OMWW plus mineral fertilization, $50 \mathrm{~W}+\mathrm{f}: 50 \mathrm{t} \mathrm{ha}^{-1}$ year $^{-1}$ of T-OMWW plus mineral fertilization, $50 \mathrm{~W}: 50 \mathrm{t}$ $\mathrm{ha}^{-1}$ year $^{-1}$ of T-OMWW only) 
The results of T-OMWW application on maize grain yield and quality suggest that T-OMWW can be used as liquid fertilizer in maize production. The control treatment, corresponding to only mineral fertilizer application, gave similar results with the only T-OMWW treatment, indicating the potential of mineral fertilizer substitution by T-OMWW, under the conditions of our study. Although not clearly shown within the first two years of maize fertigation with T-OMWW, it seems that there is an advance in grain yield with applying the T-OMWW at the lower rate of $25 \mathrm{t}$ per ha.

\subsection{Soil Properties}

The effect of T-OMWW application on soil properties was not obvious following the first year of application (results can be found in Kokkora et al., 2015). The second year of application gave a clearer picture of the effects of T-OMWW on soil properties, although again the differences between the treatments were not significant.

As shown in Table 4, there was a trend for gradual increase in soil EC following the application of greater quantities of T-OMWW. Other research work has also shown increase in the EC of a clayloam soil after the implementation of OMWW processed in stabilizing tanks (Siera, Martin, Garau, \& Cruañasm, 2007). This observation implies that caution is required in continuous application of T-OMWW to soils with high clay content, due to potential increase in salts concentration, and/or salinity sensitive crops. Soil sodium content also seemed to increase with T-OMWW application (Table 3). Magdich et al. (2013) observed significant increase in soil Na content following the successive 3-year application of OMWW at rates higher than $50 \mathrm{~m}^{3} \mathrm{ha}^{-1}$ to sandy soil. Due to the fact that our soil was rich in $\mathrm{Mg}$ and $\mathrm{Ca}$ (mean values at the end of the growing season was approximately 1436 and $3213 \mathrm{mg} \mathrm{kg}^{-1}$, respectively), sodicity problems were not an issue in this soil. Problems may arise, however, with the continuous application of T-OMWW in the case of soils poor in total salts and/or sodium sensitive crops.

Soil extractable K was practically unaffected by the different treatments (Table 4), although there was a slight tendency to increase by combining T-OMWW and inorganic $\mathrm{K}$ fertilization. At the end of the first growing season, soil extractable $\mathrm{K}$ was at the level of approximately $383 \mathrm{mg} \mathrm{kg}^{-1}$, while at the end of the second growing season was at least $516 \mathrm{mg} \mathrm{kg}^{-1}$. This finding indicates that the application of T-OMWW only, with no inorganic $\mathrm{K}$ addition, was capable to meet crop $\mathrm{K}$ requirements and also to increase soil $\mathrm{K}$ availability.

Soil available $\mathrm{P}$ content increased with the application of mineral fertilizer $\mathrm{P}$ and the combination of T-OMWW with reduced mineral fertilizer $\mathrm{P}$ addition. Our soil was poor in available phosphorus and the mineral fertilizer $\mathrm{P}$ addition in the control treatment aimed both at meeting crop $\mathrm{P}$ requirements and also enriching soil $\mathrm{P}$ levels. Indeed, the mineral P fertilization met crop requirements and increased soil P levels by approximately $41 \%$ in comparison to the soil $\mathrm{P}$ levels at the end of the first growing season. The combination of reduced mineral fertilizer $\mathrm{P}$ addition and T-OMWW further increased soil $\mathrm{P}$ levels (approximately $55 \%$ increase compared to control soil P levels at the end of the first growing season). The application of only T-OMWW slightly increased soil P levels by about 7\%. These results indicate the potential of T-OMWW to increase soil available P levels. In the case, however, of soils poor in $\mathrm{P}$, the combined application of T-OMWW and mineral fertilizer P seems as the most favorable option.

Soil O.M. content was not affected by T-OMWW application (mean soil O.M. content was $1.2 \%$ within the top $30 \mathrm{~cm}$ ). Mean soil $\mathrm{pH}$ was 6.6. As for soil nitrogen, mean total $\mathrm{N}$ content was $1.0 \mathrm{~g} \mathrm{~kg}^{-1}$, the residual nitrate- $\mathrm{N}$ content was $29.8 \mathrm{mg} \mathrm{kg}^{-1}$ and the residual ammonium-N content was negligible (less than $2.5 \mathrm{mg} \mathrm{kg}^{-1}$ ) for all treatments. Soil residual mineral $\mathrm{N}$ corresponds to approximately $148 \mathrm{~kg}$ nitrate- $\mathrm{N}$ per ha. This is a relatively high value and may lead to increased nitrate leaching losses during winter. T-OMWW application at the rate of $50 \mathrm{t}$ per ha was capable to meet crop $\mathrm{N}$ requirements and increase soil $\mathrm{N}$ availability, which suggests therefore that the extra fertilizer $\mathrm{N}$ added with the treatment of $50 \mathrm{~W}+\mathrm{f}$ (combining T-OMWW applied at $50 \mathrm{t}$ per ha along with mineral fertilizer N), possibly leached below the top $30 \mathrm{~cm}$ of soil during the growing season, hence posing a serious threat to the environment. It is evident from these results that no addition of mineral fertilizer $\mathrm{N}$ was necessary with the application of $50 \mathrm{t}$ of T-OMWW per ha. 
Table 4. Indicative topsoil (0-0.3 $\mathrm{m}$ depth) properties following two years T-OMWW application by drip irrigation to maize cultivation on clay loam soil. (C: Control (mineral fertilization only), $25 \mathrm{~W}+\mathrm{f}: 25 \mathrm{tha}^{-1}$ year $^{-1}$ of T-OMWW plus mineral fertilization, $50 \mathrm{~W}+\mathrm{f}: 50 \mathrm{t} \mathrm{ha}^{-1} \mathrm{year}^{-1}$ of T-OMWW plus mineral fertilization, $50 \mathrm{~W}$ : $50 \mathrm{tha}^{-1}$ year $^{-1}$ of T-OMWW only)

\begin{tabular}{lllll}
\hline & $\mathrm{EC}\left(\mathrm{mS} \mathrm{cm}^{-1}\right)$ & $\mathrm{Na}\left(\mathrm{mg} \mathrm{kg}^{-1}\right)$ & $\mathrm{K}\left(\mathrm{mg} \mathrm{kg}^{-1}\right)$ & $\mathrm{P}$ Olsen $\left(\mathrm{mg} \mathrm{kg}^{-1}\right)$ \\
\hline $\mathrm{C}$ & $0.5^{\mathrm{a}}(0.06)$ & $158.0^{\mathrm{a}}(6.06)$ & $524.3^{\mathrm{a}}(9.18)$ & $8.3^{\mathrm{a}}(1.85)$ \\
$25 \mathrm{~W}+\mathrm{f}$ & $0.6^{\mathrm{a}}(0.06)$ & $228.0^{\mathrm{a}}(19.63)$ & $555.7^{\mathrm{a}}(5.31)$ & $9.0^{\mathrm{a}}(1.15)$ \\
$50 \mathrm{~W}+\mathrm{f}$ & $0.8^{\mathrm{a}}(0.17)$ & $194.3^{\mathrm{a}}(47.28)$ & $540.0^{\mathrm{a}}(31.58)$ & $9.3^{\mathrm{a}}(1.21)$ \\
$50 \mathrm{~W}$ & $0.7^{\mathrm{a}}(0.23)$ & $240.3^{\mathrm{a}}(2.71)$ & $516.7^{\mathrm{a}}(13.57)$ & $6.3^{\mathrm{a}}(0.87)$ \\
\hline
\end{tabular}

Note. Numbers in brackets are standard error of mean. Columns labeled with the same lower case letter are not significantly different $(\mathrm{P}>0.05)$.

EC: Electrical conductivity.

\section{Conclusions}

The results of the present study showed the utilization potential of treated olive mill wastewater, by microfiltration and XAD4 resin, as liquid fertilizer in maize production. Plant and soil analysis showed that T-OMWW was capable to meet crop requirements in N, P and K, and also to increase soil N, P and K availability. In a soil poor in available $\mathrm{P}$, the combined application of T-OMWW and fertilizer $\mathrm{P}$ was necessary to substantially increase soil available P levels. A non-significant tendency for increasing soil $\mathrm{Na}$ and EC levels and reducing grain yield was observed with the higher rate of T-OMWW application of $50 \mathrm{t}$ per ha. These results indicate that for sustainable agriculture, it may be safer to apply the T-OMWW at the lower rate of $25 \mathrm{t}$ per ha per year, or to consider the application of $50 \mathrm{t}$ per ha every other year. Further research work is necessary to evaluate the long-term effects of T-OMWW application on soil quality and crop production.

\section{Acknowledgments}

This research has been co-financed by the European Union (European Social Fund - ESF) and Greek national funds through the Operational Program "Education and Lifelong Learning" of the National Strategic Reference Framework (NSRF) - Research Funding Program: ARCHIMEDES III. Investing in knowledge society through the European Social Fund.

\section{References}

Allen, R. G., Pereira, L. S., Raes, D., \& Smith, M. (1998). Crop Evapotranspiration: Guidelines for Computing Crop Water Requirements. Irrigation and Drainage Paper 56, Rome: United Nations Food and Agriculture Organization (FAO).

Barbera, A. C., Maucieri, C., Cavallaro, V., Ioppolo, A., \& Spagna, G. (2013). Effects of olive mill wastewater on soil properties and crops, a review. Agricultural Water Management, 119, 43-53. http://dx.doi.org/10.1016/j.agwat.2012.12.009

Barbera, A. C., Maucieri, C., Ioppolo, A., Milani, M., \& Cavallaro, V. (2014). Effects of olive mill wastewater physic-chemical treatments on polyphenol abatement and Italian ryegrass (Lolium multiflorum Lam.) germinability. Water Research, 52, 275-281. http://dx.doi.org/10.1016/j.watres.2013.11.004

Belaqziz, M., Lakhal, E. K., Mbouobda, H. D., \& El Hadrami, I. (2008). Land spreading of olive mill wastewater: effect on maize (Zea Mays) crop. Journal of Agronomy, 7(4), 297-305.

Berr, C., Porter, F., Carriere, I., Akbaraly, T. N., Feart, C., Gourlet, V., ... Ritchie. K. (2009). Olive oil and Cognition: Results from the three-city study. Dementia and Geriatric Cognitive Disorders, 28(4), 357-364. http://dx.doi.org/10.1159/000253483

Cassano, A., Conidi, C., \& Drioli, E. (2011). Comparison of the performance of UF membranes in olive mill wastewaters treatment. Water Research, 45, 3197-3204. http://dx.doi.org/10.1016/j.watres.2011.03.041

Cereti, C. F., Rossinim, F., Federici, F., Quaratino, D., Vassilev, N., \& Fenice, M. (2004). Reuse of microbially treated olive mill wastewater as fertilizer for wheat (Triticum durum Desf.). Bioresource Technology, 91, 135-140. http://dx.doi.org/10.1016/S0960-8524(03)00181-0

Chartzoulakis, K., Psarras, G., Moutsopoulou, M., \& Stefanoudaki, E. (2010). Application of olive mill 
wastewater to a Cretan olive orchard: effects on soil properties, plant performance and the environment. Agriculture, Ecosystems and Environment, 138, 293-298. http://dx.doi.org/10.1016/j.agee.2010.05.014

Covas, M. I. (2007). Olive oil and the cardiovascular system. Pharmacological Research, 55, 175-186. http://dx.doi.org/10.1016/j.phrs.2007.01.010

Escrich, E., Moral, R., \& Solanas, M. (2011). Olive oil, an essential component of the Mediterranean diet, and breast cancer. Public health nutrition, 14(12A), 2323-2332. http://dx.doi.org/10.1017/S1368980011002588

Hanifi, S., \& El Hadrami, I. (2008). Phytotoxicity and fertilising potential of olive mill wastewaters for maize cultivation. Agronomy for Sustainable Development, 28, 313-319. http://dx.doi.org/10.1051/agro:2007047

Kokkora, M., Vyrlas, P., Papaioannou, C., Petrotos, K., Gkoutsidis, P., Leontopoulos S., \& Makridis, C. (2015). Agricultural use of microfiltered olive mill wastewater: effects on maize production and soil properties. Agriculture and Agricultural Science Procedia, 4, 416-424. http://dx.doi.org/10.1016/j.aaspro.2015.03.047

Magdich, S., Ben Ahmed, C., Jarboui, R., Ben Rouina, B., Boukhris, M., \& Ammar, E. (2013). Dose and frequency dependent effects of olive mill wastewater treatment on the chemical and microbial properties of soil. Chemosphere, 93,1896-1903. http://dx.doi.org/10.1016/j.chemosphere.2013.06.066

Mahajan, S., \& Tuteja, N. (2005). Cold, salinity and drought stresses: an overview. Archives of Biochemistry and Biophysics, 444, 139-158. http://dx.doi.org/10.1016/j.abb.2005.10.018

Massoudinejad, M. R., Arman, K., \& Aghayani, E. (2014). Ecological risk assessment to olive oil mill wastewater (OMW) with bioassay on plant species. Ecology, Environment and Conservation, 20(1), 229-234.

Mekki, A., Dhouib, A., \& Sayadi, S. (2007). Polyphenols dynamics and phytotoxicity in a soil amended by olive mill wastewaters. Journal of Environmental Management, 84, 134-140. http://dx.doi.org/10.1016/j.jenvman.2006.05.015

Montemurro, F., Diacono, M., Vitti, C., \& Ferri, D. (2011). Potential Use of Olive Mill Wastewater as Amendment: Crops Yield and Soil Properties Assessment. Communications in Soil Science and Plant Analysis, 42, 2594-2603. http://dx.doi.org/10.1080/00103624.2011.614035

Moraetis, D., Stamati, F. E., Nikolaidis, N. P., \& Kalogerakis, N. (2011). Olive mill wastewater irrigation of maize: Impacts on soil and groundwater. Agricultural Water Management, 98, 1125-1132. http://dx.doi.org/10.1016/j.agwat.2011.02.006

Oktem, A., Oktem, A. G., \& Emeklier, H. Y. (2010). Effect of nitrogen on yield and some quality parameters of sweet corn. Communications in Soil Science and Plant Analysis, 41(7), 832-847. http://dx.doi.org/10.1080/00103621003592358

Oktem, A., Ulger, A. C., \& Kirtok, Y. (2001). The effect of different doses and intrarow spaces on grain yield and some agronomic characteristics of popcorn (Zea mays everta Sturt.). Journal of the Agricultural Faculty at Cukurova University, 16(2), 83-92.

Petrotos, K. B., Gkoutsidis, P. E., Kokkora, M. I., Giankidou, K. G., \& Tsagarelis, A. G. (2013). A study on the kinetics of olive mill wastewater (OMWW) polyphenols adsorption on the commercial XAD4 macroporous resin. Desalination and Water Treatment, 51, 2021-2029. http://dx.doi.org/10.1080/19443994.2013.734479

Petrotos, K. B., Lellis, T., Kokkora, M. I., \& Gkoutsidis, P. E. (2014). Purification of olive mill wastewater using microfiltration membrane technology. Journal of Membrane and Separation Technology, 3(1), 50-55.

Rahmanian, N., Jafari, S. M., \& Galanakis, C. M. (2014). Recovery and removal of phenolic compounds from olive mill wastewater. Journal of the American Oil Chemists' Society, 91, 1-18. http://dx.doi.org/10.1007/s11746-013-2350-9

Riedell, W. E. (2014). Nitrogen fertilizer applications to maize after alfalfa: grain yield, kernel composition, and plant mineral nutrients. Journal of Plant Nutrition, 37, 2026-2035. http://dx.doi.org/10.1080/01904167.2014.911892

Russo, C. (2007). A new membrane process for the selective fractionation and total recovery of polyphenols, water and organic substances from vegetation waters (VW). Journal of Membrane Science, 288(1-2), 239-246. http://dx.doi.org/10.1016/j.memsci.2006.11.020

Sierra, J., Martí, E., Garau, A., \& Cruañasm, R. (2007). Effects of the agronomic use of olive oil mill wastewater: Field experiment. Science of the Total Environment, 378, 90-94. 
http://dx.doi.org/10.1016/j.scitotenv.2007.01.009

Weisz, G. M., Schneider, L., Schweiggert, U., Kammerer, D. R., \& Carle, R. (2010). Sustainable sunflower processing - I. Development of a process for the adsorptive decolorization of sunflower [Helianthus annuus L.] protein extracts. Innovative Food Science and Emerging Technologies, 11, 733-741. http://dx.doi.org/ 10.1016/j.ifset.2010.05.005

Zaglis, D. P., Arvaniti, E. C., Papadakis, V. G., \& Paraskeva, C. A. (2013). Sustainability analysis and benchmarking of olive mill wastewater treatment methods. Journal of Chemical Technology and Biotechnology, 88(5), 742-750. http://dx.doi.org/10.1002/jctb.4036

Zaglis, D. P., Vavouraki, A. I., Kornaros, M. E., \& Paraskeva, C. A. (2015). Purification of olive mill wastewater phenols through membrane filtration and resin adsorption/desorption. Journal of Hazardous Materials, 285, 69-76. http://dx.doi.org/10.1016/j.jhazmat.2014.11.038

Zirehpour, A., Jahanshahi, M., \& Rahimpour, A. (2012). Unique membrane process integration for olive oil mill wastewater purification. Separation and Purification Technology, 96, 124-131. http://dx.doi.org/10.1016/j.seppur.2012.05.028

\section{Copyrights}

Copyright for this article is retained by the author(s), with first publication rights granted to the journal.

This is an open-access article distributed under the terms and conditions of the Creative Commons Attribution license (http://creativecommons.org/licenses/by/3.0/). 